that 32 out of our 33 patients had developed thrombocytopenia before any other drug was given. The one patient who had a haemorrhage on the fifth day of treatment received Darafan on Day 0, and even he had had thrombocytopenia on admission. Therefore, it is concluded that drugs played no part in the pathogenesis of thrombocytopenia in these patients.

\section{Conclusion}

Thrombocytopenia is the rule in the acute attack of malaria, and it is not associated with depletion of other coagulation factors in the mild case. We suggest that the platelets are removed at an excessive rate from the circulating blood, probably by the reticuloendothelial system, and that they are in some way altered immunologically, which assists in their removal.

It must be realized that thrombocytopenia can occur in malaria in the absence of intravascular coagulation, and that heparin should be withheld in such cases until other evidence is produced of disordered coagulation, when its use might then be justified.

We would like to thank Colonel R. M. Vanreenen, late R.A.M.C., Major M. J. G. Thomas, R.A.M.C., and Mr. E. Ellis, all lately of the Far East Command Laboratory at the British Military Hospital, Singapore, for their encouragement and hard work; Brigadier T. P. H. McKelvey, late R.A.M.C., and Colonel W. O'Brien, late
R.A.M.C., for many helpful suggestions in the preparation of this paper; and Mrs. Irwin for her secretarial help.

Requests for reprints should be sent to Major P. J. Beale, Royal Army Medical College, Millbank, London S.W.1.

\section{References}

Abele, D. C., Tobie, J. E., Hill, I. G., Contacos, P. G., and Evans, C. B. (1965). American Journal of Tropical Medicine and Hygiene, 14, 191.

Beale, P. J., and Coni, N. K. (1970). Annals of Tropical Medicine and Parasitology, 64, 243.

Conrad, M. E. (1969). Annals of Internal Medicine, 70, 134.

Curtain, C. C., Kidson, C., Champness, D. L., and Gorman, J. G. (1964). Nature, 203, 1366.

Dennis, L. H., and Conrad, M. E. (1968). Lancet, 1, 769.
Dennis, L. H., Eichelberger, J. W., jun., Von Doenhoff, A. E., jun., and Conrad, M. E. (1966). Military Medicine, 131, 1107.

Dennis, L. H., Eichelberger, J. W., Inman, M. M., and Conrad, M. E. (1967). Blood, 29, 713.

Devakul, K., Harinasuta, T., and Reid, H. A. (1966). Lancet, $2,886$.

Hill, G. J., Knight, V., and Jeffery, G. M. (1964). Lancet, 1, 240.

McKelvey, T. P. H., et al. (1971). Transactions of the Royal Society of Tropical Medicine and Hygiene, 65, 286.

Mancini, G., Vaerman, J. P., Carbonara, A. O., and Heremans, J. F. (1964). Proceedings of Eleventh Colloquium on the Protides of the Biological Fluids (Bruges, 1963), ed. Peeters, H. Amsterdam, Elsevier.

Oski, F. A., Naiman, J. L., and Diamond, L. K. (1963). New England fournal of Medicine, 268, 1423.

Shulman, N. R., Neva, F. A., Sheagren, J. N., and Canfield, C. J. (1970). Annals of Internal Medicine, 73, 295 .

Tobie, J. E., Wolff, S. M., and Jeffery, G. M. (1966). Lancet, 2, 300.

Turner, M.'W., Voller, A., and McFarlane, H. (1966). fournal of Tropical Medicine and Hygiene, 69, 99.

World Health Organization (1967). Technical Report Series, No. 375, p. 56.

Zuckerman, A. (1969). Bulletin of the World Health Organization, 40, 55.

\title{
Cardiovascular Effects of Methylmethacrylate Cement
}

\author{
DOUGLAS J. PEEBLES， RICHARD H. ELLIS， S. D. K. STRIDE， B. R. J. SIMPSON
}

British Medical fournal, 1972, 1, 349-351

\section{Summary}

Experiments were carried out on dogs in an attempt to identify the mechanisms underlying the systemic hypotension associated with the application of acrylic cement substances to raw bone surfaces, as in reconstructive hip surgery. Intravenous injection of the liquid component of such cements (monomeric methylmethacrylate) into six dogs produced a significant fall in blood pressure together with an increase in heart rate and cardiac output. This seemed to be due to peripheral vasodilatation caused directly by the monomer and not through the release of histamine. Absorption of free monomer from the mixed cement into the systemic circulation at operation is likely to have the same effect. Precautionary measures can be taken and groups of patients who are especially at risk can be identified, thus reducing the hazards of total hip replacement.

\footnotetext{
Department of Anaesthesia and the Anaesthetic Unit, the London Hospital, London E1 1BB

DOUGLAS J. PEEBLES, M.B., B.S., F.F.A.R.C.s., Senior Registrar (Present appointment: Consultant Anaesthetist, Sydenham Children's Hospital, appointment: Consultant Anaesthetist,

RICHARD H. ELLIS, M.B., B.S., F.F.A.R.c.s., Lecturer (Present appointment: Consultant Anaesthetist, St. Bartholomew's Hospital, London EC1A 7BE)

S. D. K. STRIDE, D.A., F.F.A.R.C.s., Consultant Anaesthetist

B. R. J. SIMPSON, D.A., F.F.A.R.C.S., Professor
}

\section{Introduction}

Several operations for the reconstruction of diseased hip joints involve the insertion of prostheses fixed in position with acrylic bone cement. These cements consist of two components, a liquid and a powder, which are mixed shortly before use. The mixture sets hard in 5 to 10 minutes, considerable heat being generated in the process (Homsy, 1969; Charnley, 1970; Frost, 1970; Jefferiss, 1971). The basis of the acrylic cements is methylmethacrylate, which can exist either in a liquid (monomeric) or a solid (polymerized) phase. The powdered component differs somewhat in the two commercially available cements (C. M. W. Bone Cement; Surgical Simplex-P) but consists essentially of methylmethacrylate in granular form and benzoyl peroxide, which serves as a coactivator. In both preparations $99.9 \%$ of the liquid component consists of methylmethacrylate monomer, the remainder being made up of water, methanol, methacrylic acid, dimethylparatoluidine (another coactivator), and hydroquinone (which prevents spontaneous polymerization). The mixing together of the liquid and the powder brings about the polymerization of the liquid monomer, which then binds together the previously polymerized powder (Charnley, 1970).

Recent reports have suggested that systemic hypotension may follow the application of the mixed cement to the raw bone surfaces (Frost, 1970; Harris, 1970; Hyland and Robins, 1970; Ling and James, 1971; Michelinakis et al., 1971; Phillips et al., 1971; Thomas et al., 1971). The fall in blood pressure is usually transient; Charnley (1970) stated that hypotension "presents itself to a noticeable degree in less than a third of cases and always the blood pressure recovers its normal levels within 3-5 minutes." However, Powell et al. (1970) recorded two cases of cardiac arrest associated with the use of acrylic cement, and we ourselves have experienced one fatality occurring during an 
impeccably administered general anaesthetic when an acute episode of hypotension led to cardiac arrest soon after the cement was applied to the femur. It was as a result of this case that the investigation now reported was undertaken.

There are several possible causes for a fall in blood pressure occurring at this time. Careful blood replacement failed to prevent the reported episodes of hypotension and it seems unlikely that hypovolaemia is the basic cause. Air and fat embolism, as well as thrombotic pulmonary embolism, have been reported in some cases (Burgess, 1970; Gresham and Kuczynski, 1970; Harris, 1970; Hyland and Robins, 1970; Charnley et al., 1971; Gresham et al., 1971; Harris, 1971; Phillips et al., 1971; Ratcliff and Clement, 1971), but there was no evidence that any of these had occurred in our patient. Inadequate suppression of powerful afferent reflexes produced by the heat generated in the freshly mixed cement might cause a reflex fall in blood pressure, but the good heat-conducting properties of the metal prosthesis and of the blood perfusing neighbouring tissues mitigate against large and sustained temperature rises (Charnley, 1970; Parsons, 1970; Jefferiss, 1971). In addition, we have found that effective extradural blockade fails to prevent the hypotension. The remaining possibilitythat one of the constituents of the cement may cause a fall in blood pressure if it gains access to the systemic circulationhas now been investigated.

\section{Method}

Experiments were carried out on adult greyhound dogs anaesthetized with thiopentone $(5 \mathrm{mg} / \mathrm{kg}$ ), intubated, and ventilated with nitrous oxide and oxygen to maintain blood gas levels within normal limits. The aorta and superior vena cava were cannulated from the groin and neck respectively, measurements of arterial and central venous pressure being made with a Cardiac Recorders transducer system. Heart rate was measured from the electrocardiogram and cardiac output by the dye dilution technique with indocyanine green and a Waters cuvette densitometer.

An initial study was made to determine which, if either, of the two components of the cement provoked a hypotensive response. A suspension of the powder in normal saline injected intravenously failed to produce any effect, but injection of small amounts of the monomer (administered as a bolus) caused transient falls in blood pressure and changes in heart rate and cardiac output.

A further study was therefore undertaken to measure the cardiovascular effects of the liquid monomer in six dogs $(22-32 \mathrm{~kg}$ in weight). The effects of an intravenous injection of $0.25 \mathrm{ml}$ were first observed and then, after an interval to allow the cardiovascular measurements to return more or less to their pre-existing levels, they were observed again after the injection of $0.5 \mathrm{ml}$. The volumes chosen for these injections had been indicated by the results of the initial study.

\section{Results}

As shown in Tables I and II, both doses of the monomer produced a significant fall in mean arterial blood pressure and a significant rise in pulse rate; only in the case of blood pressure was the effect of the $0.5-\mathrm{ml}$ dose significantly greater than that of the $0.25-\mathrm{ml}$ dose $(t=3.81 ; 0.02>\mathrm{P}>0.01)$. Both doses were followed by an increase in cardiac output in most cases (Table III), but the mean increase was statistically significant only with the smaller dose. The mean duration of hypotension after the $0 \cdot 25-\mathrm{ml}$ dose (five dogs) was $13 \cdot 2 \mathrm{sec}$ and after the $0.5-\mathrm{ml}$ dose (six dogs) $16.4 \mathrm{sec}$, the difference not being statistically significant. No changes in central venous pressure were detected.

The main underlying mechanism seemed to be peripheral vasodilatation. To determine whether this was produced by
TABLE I-Mean Arterial Blood Pressure in mm $\mathrm{Hg}$ before and after Intravenous Injections of Methylmethacrylate Monomer in Six Days

\begin{tabular}{|c|c|c|c|c|c|c|c|}
\hline \multirow{2}{*}{\multicolumn{2}{|c|}{ Dog }} & \multicolumn{3}{|c|}{$0.25-\mathrm{ml}$ Injection } & \multicolumn{3}{|c|}{$0.5-\mathrm{ml}$ Injection } \\
\hline & & Before & After & $\begin{array}{c}\text { Duration } \\
\text { of Fall } \\
\text { (sec.) }\end{array}$ & Before & After & $\begin{array}{c}\text { Duration } \\
\text { of Fall } \\
\text { (sec.) }\end{array}$ \\
\hline \multirow[t]{2}{*}{$\begin{array}{l}1 \\
2 \\
3 \\
4 \\
5 \\
6\end{array}$} & $\begin{array}{l}\ldots \\
\cdots \\
\cdots \\
\cdots\end{array}$ & $\begin{array}{l}212 \\
188 \\
206 \\
206 \\
200 \\
176\end{array}$ & $\begin{array}{l}185 \\
140 \\
188 \\
173 \\
200 \\
149\end{array}$ & $\begin{array}{l}17.5 \\
12.0 \\
12.0 \\
12.0 \\
12.5\end{array}$ & $\begin{array}{l}212 \\
188 \\
206 \\
206 \\
200 \\
188\end{array}$ & $\begin{array}{l}174 \\
117 \\
166 \\
166 \\
173 \\
144\end{array}$ & $\begin{array}{l}26.5 \\
14.0 \\
12.0 \\
12.0 \\
12.5 \\
15.0\end{array}$ \\
\hline & & \multicolumn{3}{|c|}{$t=4.00 ; 0.02>P>0.01$} & \multicolumn{3}{|c|}{$t=5.82 ; 0.05>\mathrm{P}>0.001$} \\
\hline
\end{tabular}

TABLE II-Heart Rate in Beats/min before and after Intravenous Injections of Methylmethacrylate Monomer in Six Dogs

\begin{tabular}{|c|c|c|c|c|c|c|}
\hline & \multirow{2}{*}{\multicolumn{2}{|c|}{ Dog }} & \multicolumn{2}{|c|}{$0 \cdot 25-\mathrm{ml}$ Injection } & \multicolumn{2}{|c|}{ 0.5-ml Injection } \\
\hline & & & Before & After & Before & After \\
\hline \multirow[t]{2}{*}{$\begin{array}{l}1 \\
2 \\
3 \\
4 \\
5 \\
6\end{array}$} & 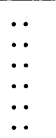 & $\begin{array}{c}\ldots \\
\ldots \\
\cdots \\
\ldots\end{array}$ & $\begin{array}{l}204 \\
108 \\
120 \\
216 \\
192 \\
144\end{array}$ & $\begin{array}{l}216 \\
216 \\
192 \\
240 \\
192 \\
144\end{array}$ & $\begin{array}{l}204 \\
120 \\
120 \\
228 \\
192 \\
144\end{array}$ & $\begin{array}{l}216 \\
240 \\
240 \\
228 \\
204 \\
144\end{array}$ \\
\hline & & & \multicolumn{2}{|c|}{$t=3.75 ; 0.02>P>0.01$} & \multicolumn{2}{|c|}{$t=3.52 ; 0.02>\mathrm{P}>0.01$} \\
\hline
\end{tabular}

TABLE III-Cardiac Output in Litres/min before and after Intravenous Injections of Methylmethacrylate in Six Dogs

\begin{tabular}{|c|c|c|c|c|c|c|}
\hline & \multirow{2}{*}{\multicolumn{2}{|c|}{ Dog }} & \multicolumn{2}{|c|}{ 0.25-ml Injection } & \multicolumn{2}{|c|}{$0.5-\mathrm{ml}$ Injection } \\
\hline & & & Before & After & Before & After \\
\hline \multirow[t]{2}{*}{$\begin{array}{l}1 \\
2 \\
3 \\
4 \\
5 \\
6\end{array}$} & $\begin{array}{l}\because \\
\because \\
\because \\
\because\end{array}$ & $\begin{array}{l}\because \\
\because \\
\because \\
\because\end{array}$ & $\begin{array}{l}4.1 \\
5.4 \\
6.1 \\
3.7 \\
3.5 \\
3.1\end{array}$ & $\begin{array}{l}4.5 \\
5.4 \\
6.9 \\
4.0 \\
3.5 \\
3.8\end{array}$ & $\begin{array}{l}4.0 \\
5.3 \\
6.1 \\
3.2 \\
3.1 \\
2.3\end{array}$ & $\begin{array}{l}4.2 \\
4.7 \\
6.4 \\
3.3 \\
3.1 \\
3.0\end{array}$ \\
\hline & & & \multicolumn{2}{|c|}{$t=2.62 ; 0.05>P>0.025$} & \multicolumn{2}{|c|}{ Not significant } \\
\hline
\end{tabular}

the substance itself or secondarily through histamine release the liquid monomer was added to the perfusion circuit of an isolated canine liver perfusion preparation (Strunin et al., 1966). In this preparation minute amounts of histamine consistently cause a fall in hepatic artery pressure and a rise in portal venous pressure (L. Strunin, personal communication), and a similar response is produced by substances known to cause histamine release. The injection of $0.25 \mathrm{ml}$ and later of $0.5 \mathrm{ml}$ of the monomer failed to elicit a histamine-like response.

\section{Discussion}

The cardiovascular responses observed in these experiments thus appeared to be due mainly to peripheral vasodilatation caused by the liquid monomer itself. It is surprising that no changes in central venous pressure were recorded, though this finding accords with recent clinical studies on the cardiovascular effects of the monomer (Phillips et al., 1971; Thomas et al., 1971). The duration of the hypotension in the dogs was much less than in human beings undergoing hip surgery (Charnley, 1970), in whom leakage of monomer into the circulation would presumably occur over a longer period.

These cardiovascular changes are likely to occur in any patients having large amounts of acrylic cement applied to vascular surfaces. However, it is possible to define groups of patients who might be particularly at risk from the transient hypotension. These include the hypertensive, the arteriosclerotic, and the elderly, who compensate poorly for sudden and severe physiological changes. Especially at risk are patients with coronary artery disease, in whom the hypotension may cause a further reduction of the already impaired coronary blood flow; the tachycardia is a further hazard to such patients since it leads to a shortening of diastole, during which the greater part of coronary filling normally occurs, and increases myocardial 
work and oxygen consumption. In patients with appreciable valvular stenosis or constrictive pericarditis the compensatory increase in cardiac output may be limited by mechanical factors and the hypotension consequently more pronounced. Similarly, patients who are unable to respond with a tachycardia may suffer disproportionately severe hypotension; this group would include those taking large amounts of digitalis and those with heart block. The risk may be increased in patients receiving betaadrenergic blocking agents (Norman and Atkinson, 1970) and in those with myxoedema. Some patients with cardiomyopathy suffer a fall in cardiac output in response to tachycardia (Goodwin, 1964) and constitute another group at risk.

The likelihood and extent of the fall in blood pressure can be minimized by ensuring adequate preoperative hydration and by careful blood replacement during the preliminary stages of the operation. The content of free monomer in the mixture varies inversely with its hardness, and Charnley (1970) recommended that the cement should not be applied until it is of a firm and doughy consistency. He also recommended that excess monomer should be allowed to evaporate by kneading and rolling the cement after mixing so as to expose as large a surface area as possible to the air. It has been suggested that venting the femoral canal during the insertion of the cement and prosthesis may reduce the intramedullary pressure and the likelihood of air and fat embolism; it may also diminish the seepage of free monomer into the circulation, but the evidence for this is at present inconclusive (Phillips et al., 1971).

\section{Conclusion}

The existence of a syndrome of acute hypotension associated with the application of acrylic cement to raw bone surfaces has been substantiated by this investigation. An understanding of the mechanisms involved in the production of the cardiovascular disturbance enables a high-risk group of patients to be defined to whom this syndrome constitutes a real and serious hazard. It is arguable that hip surgery involving the use of currently available cements should rarely, if ever, be performed on these individuals. Alternative operations for the total replacement of diseased hip joints without the use of cement have been developed and are reported to give satisfactory results in prac- tised hands (Ring, 1971; J. L. Sbarbaro, jun., personal communication). Recent suggestions for the more widespread use of acrylic cement in large quantities (Welsh et al., 1971) should be viewed with caution.

We thank Dr. A. M. C. Jennings for his helpful advice and criticism and for his statistical analysis. The assistance of the technical staff of the London Hospital Anaesthetic Research Laboratories is gratefully acknowledged, as is the invaluable help of Mr. Jeffrey Huntingdon, of Electronic and X-ray Applications Ltd., Basingstoke.

Reprints are available from Dr. Richard H. Ellis, Department of Anaesthesia, St. Bartholomew's Hospital, London EClA 7BE.

\section{References}

Burgess, D. M. (1970). British Medical fournal, 3, 688.

Charnley, J. (1970). Acrylic Cement in Orthopaedic Surgery. Edinburgh, Livingstone.

Charnley, J,, Murphy, J. C. M., and Pitkeathly, D. A. (1971). British Medical fournal, 3,474 .

Frost, P. M. (1970). British Medical fournal, 3, 524

Goodwin, J. F. (1964). British Medical fournal, 1, 1595.

Gresham, C. A., and Kuczynski, A (1970). British Medical fournal, 3, 465.

Gresham, C. A., and Kuczynski, A. (1970). British Medical fournal, 3, 465. resham, G. A., Ku Fournal, $2,617$.

Harris, N. (1970). British Medical fournal, 3, 523.

Harris, N. (1971). British Medical fournal, 3, 47.

Homsy, C. A. (1969). Paper presented at the Joint Workshop on Total Hip Replacement and Skeletal Attachment.

Hyland, J., and Robins, R. H. C. (1970). British Medical fournal, 4, 176.

Jefferiss, C. D. (1971). British Medical fournal, 2, 382.

Ling, R. S. M., and James, M. L. (1971). British Medical fournal, 2, 404

Michelinakis, E., Morgan, R. H., and Curtis, P. J. (1971). British Medical fournal, 3, 639 .

Norman, J., and Atkinson, S. A. (1970). British fournal of Anaesthesia, 42, 592

Parsons, D. W. (1970). British Medical fournal, 3, 710

Phillips, H., Cole, P. V., and Lettin, A. W. F. (1971). British Medical fournal, 3,460 .

Powell, J. N., McGrath, P. J., Lahiri, S. K., and Hill, P. (1970). British Medical fournal, 3, 326.

Ratcliff, A. H. C., and Clement, J. A. (1971). British Medical fournal, 2, 532. Ring, P. A. (1971). Annals of the Royal College of Surgeons of England, 48, 344

Strunin, L., Weaver, E. J. M., Smith, J., and Simpson, B. R. J. (1966). British fournal of Anaesthesia, 38, 412.

Thomas, T. A., Sutherland, I. C., and Waterhouse, T. D. (1971). Anaesthesia, 26, 298.

Welsh, R. R., Pilliar, R. M., and MacNab, I. (1971). fournal of Bone and foint Surgery, 53A, 963.

\section{PRELIMINARY COMMUNICATION}

\section{Effect of Mechanical Loading on Ventilatory Response to $\mathrm{CO}_{2}$ and $\mathrm{CO}_{2}$ Excretion}

\author{
T. J. H. CLARK, G. M. COCHRANE
}

British Medical fournal, 1972, 1, 351-353

\section{Summary}

The ventilatory response to $\mathrm{CO}_{2}(\mathrm{~S})$ and respiratory exchange ratio have been measured in 10 healthy subjects breathing naturally and through added resistive

Guy's Hospital, London S.E.1 \& Brompton Hospital, London S.W.3 T. J. H. CLARK, M.D., M.R.C.P., Consultant Physician

Brompton Hospital, London S.W.3

G. M. COCHRANE, M.B., B.S., M.R.c.P., House Physician loads. The changes in these values produced by the added loads were shown to be correlated with the unloaded $\mathrm{CO}_{2}$ responsiveness. The results indicated that poorly responsive individuals had a greater depression of ventilatory response to $\mathrm{CO}_{2}$ and were more liable to retain $\mathrm{CO}_{2}$.

These observations raise the possibility that the constitutional $\mathrm{CO}_{2}$ responsiveness of an individual influences the alveolar ventilation achieved in the presence of airways obstruction. The propensity to develop respiratory failure may thus be conditioned by the premorbid $\mathrm{CO}_{2}$ responsiveness.

\section{Introduction}

Retention of $\mathrm{CO}_{2}$ occurs in some patients with airways obstruction but the mechanical abnormality does not appear to be entirely responsible for the development of respiratory failure (Clark, 1968; Lane, Howell, and Giblin, 1968). The poor correlation observed between the forced expiratory volume in one second $\left(\mathrm{FEV}_{1}\right)$ and $\mathrm{CO}_{2}$ tension suggests that in addition to airflow obstruction other important factors modify the drive to 